\title{
Thoughts and Attitudes of Adults About Medicines Used for COVID-19; A Descriptive Study
}

\section{Erişkin Bireylerin COVID-19’a Yönelik Kullanılan İlaçlarla İlgili Düşünce ve Tutumları; Tanımlayıcı Bir Çalışma}

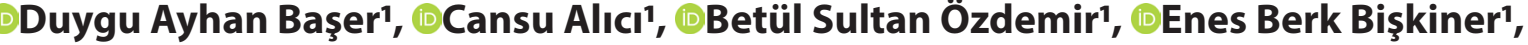 \\ DAsena Merve Oflaz', @izzet Fidanci', @Hilal Aksoy', @Mustafa Cankurtaran²
}

${ }^{1}$ Hacettepe University School of Medicine Department of Family Medicine, Ankara, Turkey

${ }^{2}$ Hacettepe University School of Medicine Department of Internal Medicine, Geriatrics, Ankara, Turkey

\begin{abstract}
Aim: With this study; it was aimed to determine the usage status and attitudes towards the drugs currently used/recommended for the treatment of COVID-19 and various medications or nutritional supplements to support immune system, and the factors affecting usage status of them, according to the condition of having COVID-19.
\end{abstract}

Material and Method: The descriptive research was conducted in Family Medicine outpatient clinics. Data were collected with a questionnaire prepared by the researchers through the internet (sites on social media) due to the pandemic. The e-questionnaire form was shared on the internet a total of 10 times at 6-day intervals.

Results: 1484 people participated, $60.8 \%$ were female, $51.5 \%$ was a healthcare professional. While $23.3 \%$ had a known disease; $19.3 \%$ of them had COVID-19 infection, 79\% of them received outpatient medication. Although not recommended, it was observed that the most used drugs were Vitamin C and antipyretic drugs, followed by vitamin $\mathrm{D}$ and antibiotics. $87.5 \%$ who have had COVID-19 infection stated that they used the drugs as suggested/written on to them. The reasons of those who did not use drugs: fear of its side effects, not seeing it necessary, using herbal products and observing and using it if necessary. People who living with a person under the age of 18 in the same household ( $p=0.042)$, who had a chronical disease $(p=0.014)$ and regular drug users $(p=0.003)$ were reported that they used COVID-19 drugs as suggested/written on them.

Conclusion: New information is emerging day by day about the treatment of COVID-19 disease, infodemic causes the spread of false information about the disease and its treatment both among the public and in scientific circles. The results of our study also support this situation. The healthcare system should be structured in accordance with the pandemic conditions in order to explain the importance of the use of medicines.

Keywords: COVID-19, medicines, nutritional supplements, infodemic
Öz

Amaç: Bu çalıșma ile; COVID-19 tedavisinde halen kullanılan/önerilen bağışıkık sistemini destekleyici çeşitli preparatlar, besin takviyeleri ve ilaçlara yönelik erişkinlerin düşünce ve tutumlarının ve kullanım durumlarını etkileyen faktörlerin belirlenmesi amaçlanmıştır.

Gereç ve Yöntem: Tanımlayıcı tipteki araşıırma Aile Hekimliği polikliniklerinde yürütülmüştür. Veriler, pandemi nedeniyle internet (sosyal medyadaki siteler) üzerinden araştırmacılar tarafından hazırlanan anket ile toplanmışıı. E-anket formu internette 6 gün arayla toplam 10 kez paylaşılmıştır.

Bulgular: 1484 kişi katıldı, \%60,8'i kadın, \%51,5'i sağlık çalışanıydı. \%23,3'ünün bilinen bir hastalığı varken; bu kişilerin \%19,3'ü COVID-19 enfeksiyonu geçirdiğini, \%79'u ayakta tedavi gördüğünü belirtti. Önerilmemesine rağmen en çok kullanılan ilaçların C vitamini ve ateş düşürücü ilaçlar olduğu, bunu D vitamini ve antibiyotiklerin takip ettiği görüldü. COVID-19 enfeksiyonu geçirenlerin \%87,5'i ilaçları kendilerine önerildiği/üzerlerine yazıldığı şekilde kullandığını belirtmiştir. Önerildiği halde ilaç kullanmayanların nedenleri: yan etkilerinden korkmak, gerekli görmemek, bitkisel ürünleri kullanmak ve gerekirse gözlemlemek ve kullanmak. Aynı hanede 18 yaşından küçük bir kişiyle yaşayanlar ( $p=0,042)$, kronik hastalığı olanlar $(p=0,014)$ ve düzenli ilaç kullananlar ( $p=0,003)$ COVID-19 ilaçlarını önerildiği/üzerlerinde yazıldığı gibı kullandıklarını bildirdiler.

Sonuç: COVID-19 hastalığının tedavisi hakkında her geçen gün yeni bilgiler ortaya çıkıyorken; infodemi, hem halk arasında hem de bilim çevrelerinde hastalık ve tedavisi hakkında yanlış bilgilerin yayılmasına neden olmaktadır. Çalışmamızın sonuçları da bu durumu desteklemektedir. Ilaç kullanımının önemini anlatabilmek için sağlık sistemi pandemi koşullarına uygun olarak yapılandırımalıdır.

Anahtar Kelimeler: COVID-19, ilaçlar, besin takviyeleri, infodemi 


\section{INTRODUCTION}

After originating in China, COVID-19 epidemic which has affected the whole world in a short period of three months, continues to threaten all humanity despite more than one year. [1] According to the data of the World Health Organization; it is seen that the number of cases originating from COVID-19 has reached $144,587,350$ and the number of deaths is $3,075,007$ worldwide. ${ }^{[2]}$

In Turkey, the first case of COVID-19 was seen on 11 March 2020 and 4 days after the first death occurred bonded to the COVID-19. During the period until 22/04/2021; total number of cases $4,446,591$ and the total number of deaths from COVID-19 is stated as 36,975. [3] $^{[3}$

Some drugs are being evaluated or developed for the management of COVID-19 from the first stage of the disease. These drugs; antivirals (eg, Remdesivir, Favipiravir), antibodies (eg Convalescent Plasma, Hyperimmune Immunoglobulins), anti-inflammatory agents (dexamethasone, statins), targeted immunomodulatory therapies (eg, Tocilizumab, Sarilumab, Anakinra, Ruxolitinib) anticoagulants (eg Heparin) and antifibrotics (eg Tyrosine Kinase Inhibitors). Different treatment modalities applied may have different effects on different disease symptoms at other stages of the disease. While viral inhibition is expected to be most effective in the early phase of infection, immunomodulatory agents are useful in hospitalized patients to prevent disease progression, and anticoagulants can be useful to prevent thromboembolic complications. Although there are many treatment modalities, studies show that the drug treatment that is initiated early and taken at the right doses in COVID-19 infection greatly prevents the progression of the disease and reduces the intensive care admission rate. [4-7] In our country, there are treatment recommendations for asymptomatic COVID-19 cases, possible/definite cases of COVID-19 with mild to moderate pneumonia and COVID-19 cases with hospitalization indication. Treatment with Hydroxychloroquine and/or Favipiravir is started in outpatients, this treatment is delivered directly to individuals by institutions affiliated to the Ministry of Health as soon as the person recover from illness. ${ }^{[8]}$ However, there is no mechanism that controls the treatment process and the use of drugs. Drug use is done with the consent of the people. It is observed that drug use of individuals is also affected due to infodemic. ${ }^{[9,10]}$ No study has been found on the use of the medicines recommended for them in case of illness and the factors affecting this.

It is known that some people use various medications or nutritional supplements (multivitamins, minerals) to support immune system in addition to the drugs for COVID-19 infection during the pandemic process. ${ }^{[11]}$ In this process, various situations such as misuse due to information pollution and various factors, drug refusal, irregular use are also encountered. No studies have been found in the literature review about this very common situation in daily practice.

With this study, it was aimed to determine the usage status and attitudes towards the drugs currently used/recommended for the treatment of COVID-19 and various medications or nutritional supplements to support immune system, and the factors affecting usage status of them, according to the condition of having COVID-19.

\section{MATERIAL AND METHOD}

The descriptive research was conducted between the dates of 20th January 2021 and 20th March 2021 in Hacettepe University Faculty of Medicine, Department of Family Medicine. The population of the research consists people over the age of 18 in Turkey. After the approval of the ethics committee, those who completely filled out the e-questionnaire form shared by the researchers on the web with "Google forms" for two months were included in the study. Epi Info 7 StatCalc was used to calculate the minimum sample size for universe whose prevalence and number are unknown, and the sample size was estimated as 384 adults, assuming 95\% confidence interval and 5\% sampling error.

The questionnaire form used in the study was prepared by the researchers by scanning the literature. In addition to 20 questions where sociodemographic data (age, gender, educational status, marital status, number of children, number of people living in the same household, presence of individuals over 65 and under 18 living in the same household, occupation, employment status, working style during the pandemic) and the disease states of the participants and their relatives during the pandemic (presence of known disease, presence of regularly used drugs, presence of an individual with COVID-19 in their vicinity, presence of quarantine due to contact) are questioned, 14 questions asked to those who had COVID-19 infection (treatment process, symptoms, positivity of COVID-19 infection in individuals in the same household, which drugs were started, whether the patient used the treatment in accordance with the treatment and dose, if not, the reasons, the use of vitamin supplements before, during and after the disease, prophylactic attitude towards drug use), 9 questions asked to those who have not had been infected (thoughts about COVID-19, thoughts about drugs and negative, use of vitamin supplements for prevention, attitude towards prophylactic drug use).

Data were collected with a questionnaire prepared by the researchers through the internet (Whats up, Facebook) due to the pandemic. The e-questionnaire form was shared on the internet a total of 10 times at 6-day intervals. Individuals who filled out the voluntary consent form, which was attached to the beginning of the questionnaire form, were able to access the questionnaire questions. People over the age of 18 who responded to all data were included in the study.

Transferring the data obtained in the study to electronic media (data entry) and statistical analysis of the data were performed using IBM SPSS Statistics Premium $23 \mathrm{~V}$ statistical computer package program licensed by Hacettepe University. Descriptive statistics were specified as distributions, as percentage, mean, median, quartiles, minimum-maximum values, and standard deviation. If necessary, the compliance 
of variables to normal distribution was checked with Kolmogorov Smirnov and Shapiro Wilk tests. For the comparison of independent two-group continuous variables conforming to normal distribution, the t-test in independent groups, the Mann Whitney $U$ test for the comparison of continuous variables with independent two groups that did not comply with the normal distribution, for categorical variables, the Pearson Chi-square test was used to evaluate whether there was a difference between the groups, and when necessary, the Fisher test in $2 \times 2$ order, ANOVA test was used to compare the means of more than two independent groups. When parametric conditions could not be provided, Kruskal Wallis variance analysis was used. It was planned to conduct correlation analysis to evaluate the linear relationship between variables, and multivariate analysis to examine the cause-effect relationship between variables. Alpha 0.05 was taken.

\section{Permissions}

Ethics committee approval of the research was obtained from Hacettepe University Non-Interventional Clinical Research Ethics Committee (Date: 19/01/2021, Decision No: GO21/123). All procedures were carried out in accordance with the ethical rules and the principles of the Declaration of Helsinki.

\section{RESULTS}

\section{Sociodemographic Features}

The average age of the participants in our study, in which 1484 people participated, was $35.94+12.42(\min =18 ; \max =81)$. Of the participants, $60.8 \%(n=902)$ were female, $84.2 \%(n=1246)$ were between $18-50$ years old, $1.6 \%$ were above 65 years old, $67.9 \%(n=1008)$ were university graduates, $59 \%(n=876)$ were married, $66.2 \%(n=982)$ of them live with 3 or more people in the same household, $8.1 \%(n=120)$ live with someone over 65 years old in the same household, and $45.1 \%(n=669)$ live with children under 18 in the same household and $51.5 \%$ $(n=764)$ was a healthcare professional, $13.3 \%(n=198)$ were not working, $70.1 \%(n=1041)$ were working full time. While $23.3 \%(n=346)$ had a known disease; $25 \%(n=371)$ of them regularly used medication.

\section{Features Related to COVID-19 Infection}

Of the participants, $19.3 \%$ ( $n=286$ ) of themselves and $65.2 \%$ $(n=967)$ of their relatives had COVID-19 infection, $23.5 \%$ $(n=349)$ of them remained in quarantine due to contact with someone with COVID-19 infection.

\section{Disease and drug use characteristics of those who had COVID-19 infection}

Of the participants who have had COVID-19 infection, 49.6\% $(n=107)$ of them had COVID-19 infection in the person (s) with whom they lived in the same household during the period when they had COVID-19 infection and 79\% $(n=215)$ of them received outpatient medication. Treatment modalities are presented in the Graphic 1.

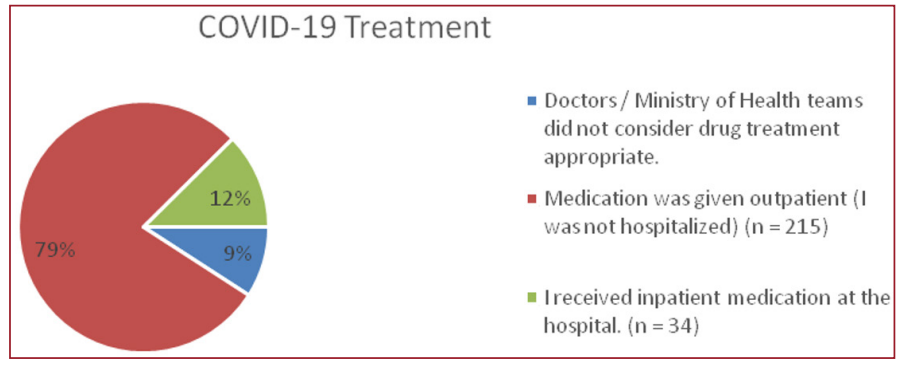

Graphic 1. Distribution of treatment modalities of participants who have had COVID-19 infection

The drugs recommended and the rates of drugs used by the participants who have had COVID-19 infection are given in the Graphic 2. Although not recommended, it was observed that the most used drugs were Vitamin $C$ and antipyretic drugs, followed by vitamin $\mathrm{D}$ and antibiotics.

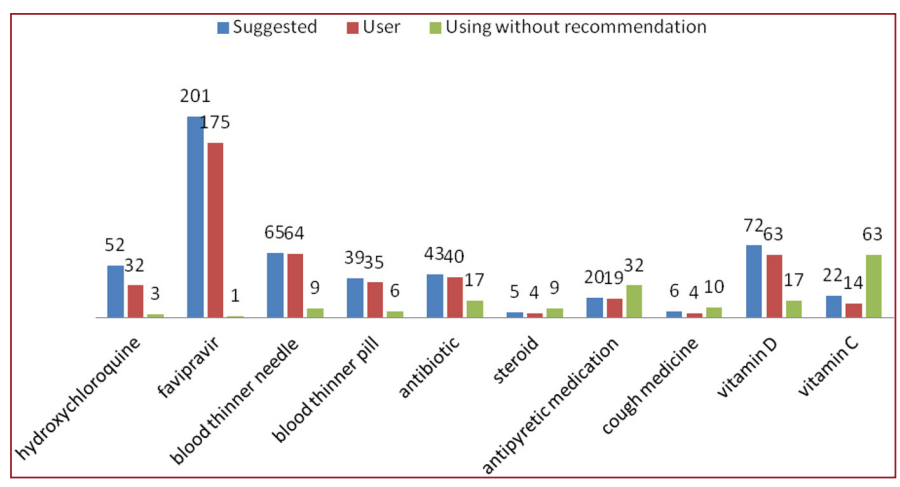

Graphic 2. The drugs recommended and the rates of drugs used by the participants who have had

Of the participants, $87.5 \%$ ( $n=188)$ who have had COVID-19 infection stated that they used the drugs as suggested/ written on to them. The reasons of those who did not use drugs as suggested/written on are in the Graphic 3. The most common reason: fear of its side effects, not seeing it necessary, using herbal products and observing and using it if necessary.

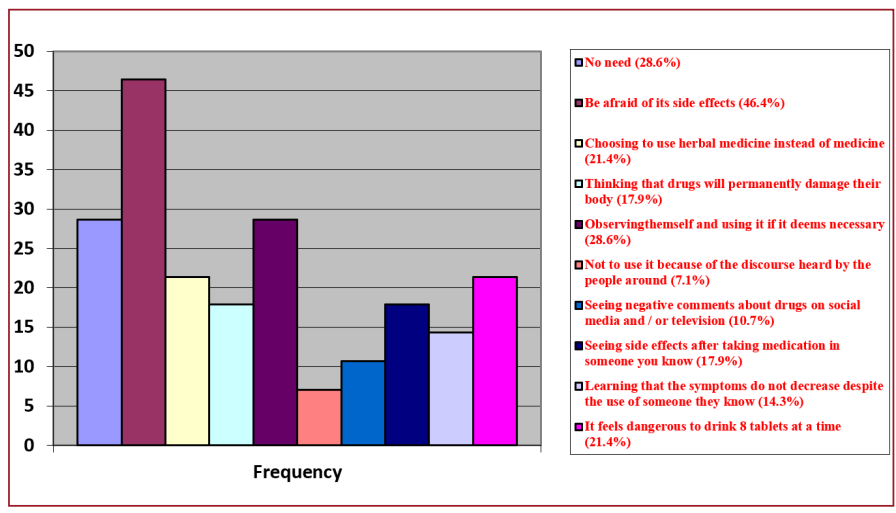

Graphic 3. The reasons of those who did not use drugs as suggested/written on 
Factors affecting the participant's use of drugs as suggested/ written on them are presented in the Table 1. People who had live a person under the age of 18 living in the same household $(p=0.042)$, who had a chronical disease $(p=0.014)$ and who were regularly drug users $(p=0.003)$ were reported that they used drugs as suggested/written on them.

While $38.4 \%$ ( $n=75$ ) of those who had COVID-19 infection were taking additional vitamin supplements to protect against COVID-19 in the pre-illness period; $75 \%(n=149)$ stated that they received additional vitamin supplements during the period of illness, and $45.4 \%(n=98)$ stated that they received additional vitamin support in the post-illness period. Of the participants who have had COVID-19 infection, 23.6\% ( $n=46)$ stated that they believed in using prophylactic drugs to protect against COVID-19.

\section{The thoughts of those who have not had COVID-19 infection on the disease and drug use}

Of the participants who did not have COVID-19 infection, $58.9 \%(n=712)$ of those stated that it was a seriously fatal disease for everyone, $67.4 \%(n=820)$ stated that they would use the drugs given by the Ministry of Health/doctors in case of having COVID-19 infection, and $23.1 \%$ were undecided about using. $40.3 \%$ stated that the drugs cannot prevent the progression of the disease, $72 \%$ stated that the drugs cannot reduce the infectiousness or were unstable, and $37.7 \%$ stated that the drugs cannot reduce your complaints/ symptoms.

Factors affecting the use of drugs to be given in case of COVID-19 infection of the participants are presented

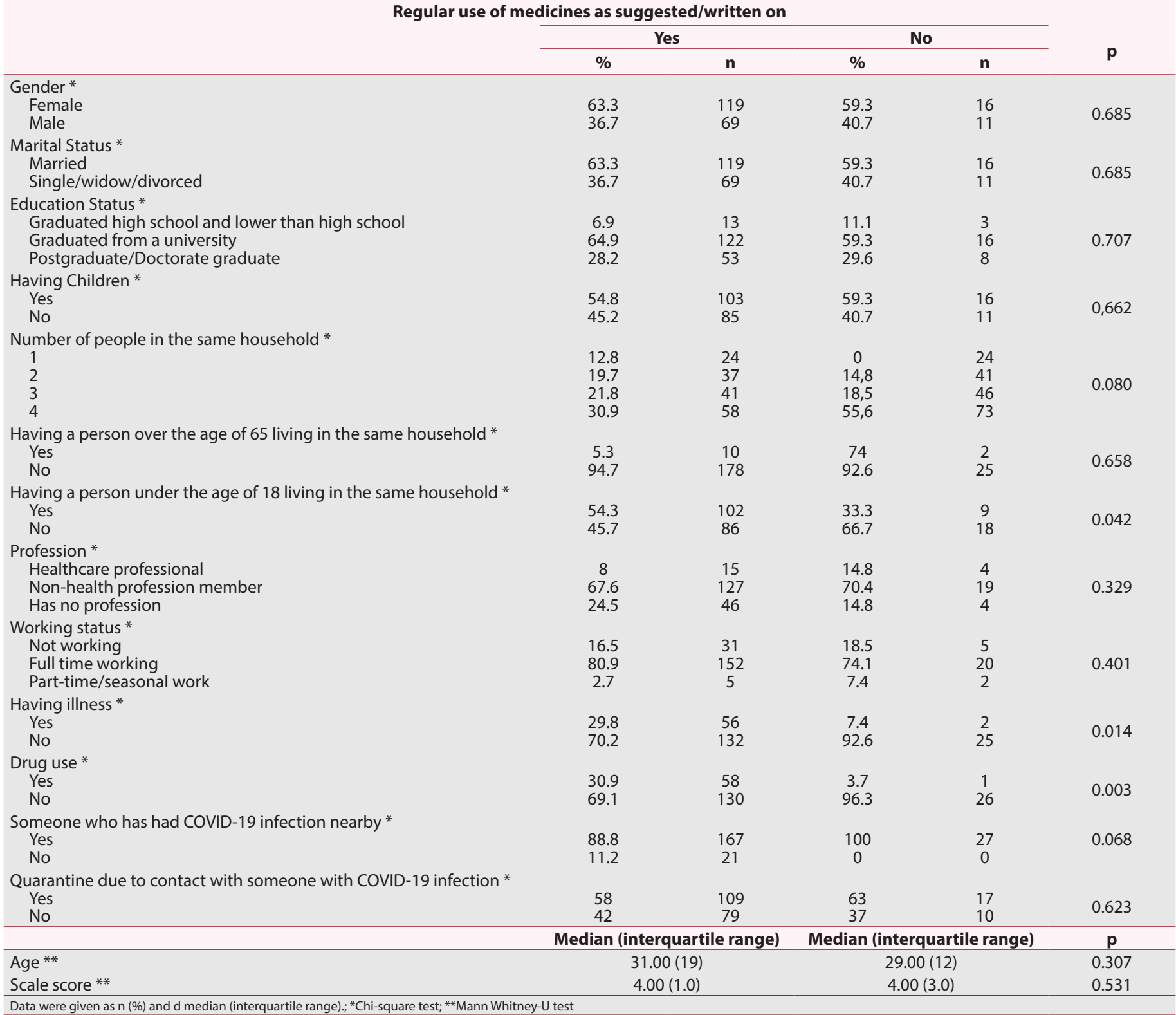


in the Table 2. People who were regularly drug users $(p=0.022)$, who not stated that the drugs cannot prevent the progression of the disease $(p<0.001)$, who not stated that the drugs cannot reduce the infectiousness or were unstable $(p<0.001)$, and who not stated that the drugs cannot reduce your complaints/symptoms $(p<0.001)$ were reported that they would use drugs given in case of having COVID-19 infection.

\section{Table 2. Factors affecting the use of drugs to be given in case of COVID-19 infection of the participants}

\section{Using medicines to be given in case of having COVID-19 infection}

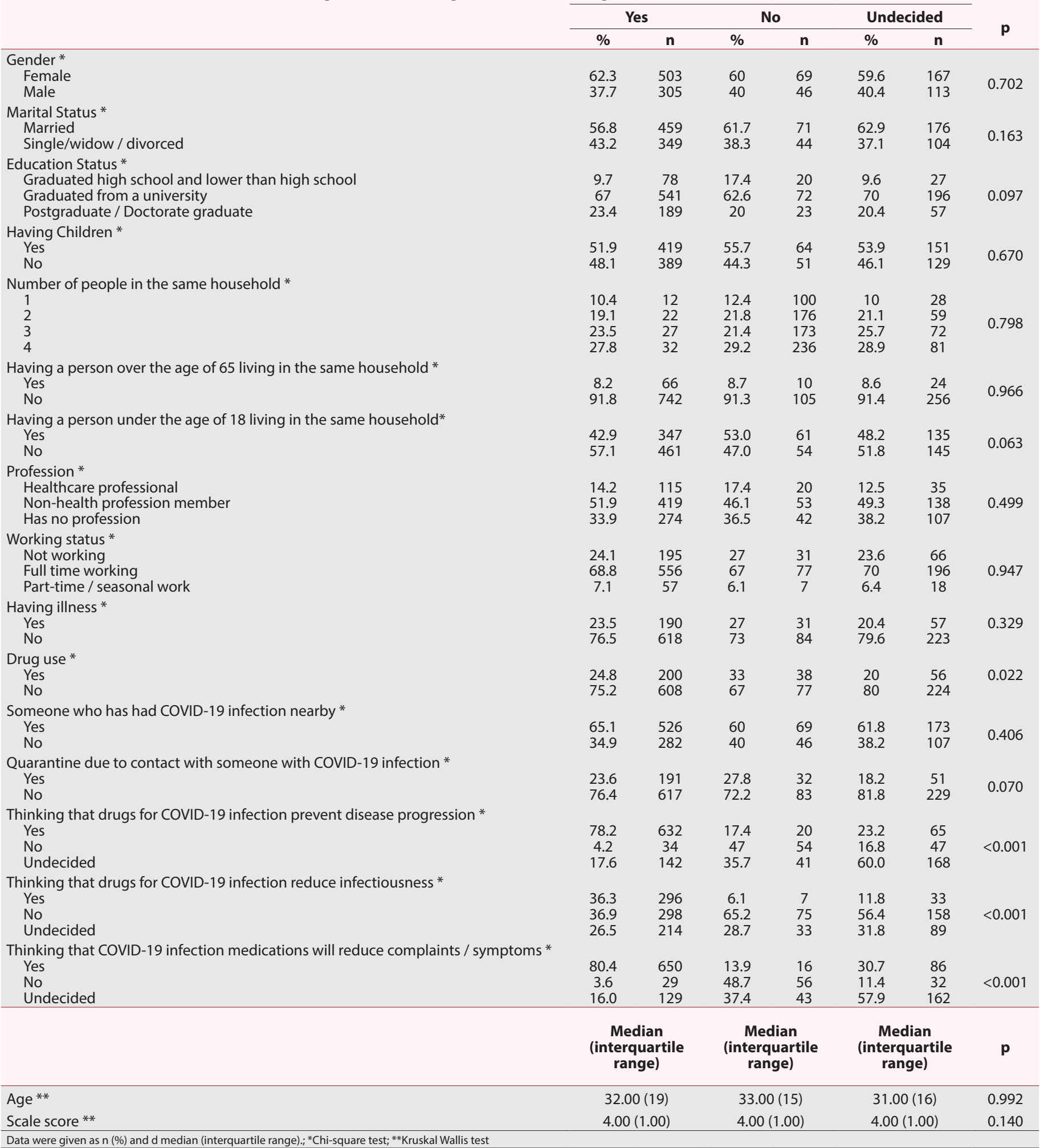


Considering the reasons for those who were reported that they would not use drugs given in case of having COVID-19 infection were: fear of side effects, thinking of to take 8 tablets at a time is dangerous, observing and thinking of using it myself, or fear that the drug will cause permanent damage. The reasons for those who do not intend to use drugs are in the Graphic 4.

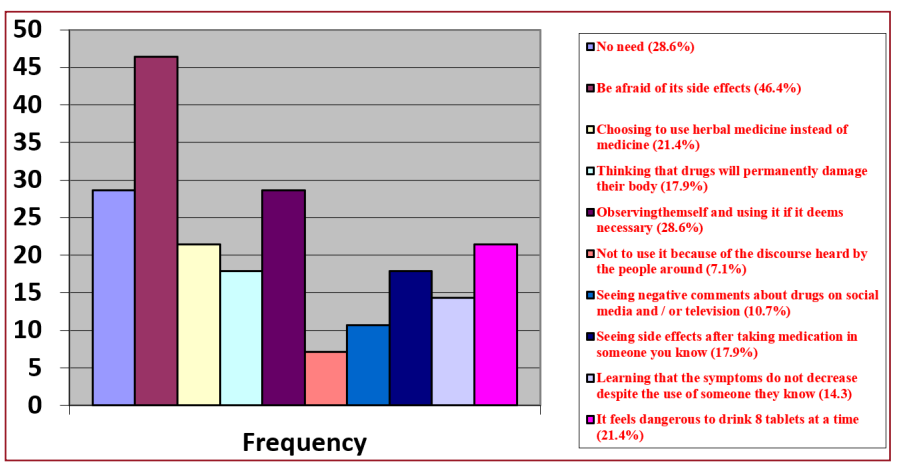

Graphic 4. The reasons for those who do not intend to use drugs

While $51.2 \%$ of those who did not have COVID-19 infection took vitamin supplements, $56.2 \%$ stated that they did not believe in using prophylactic drugs (to avoid the disease).

\section{DISCUSSION}

In our study, which evaluated the use of drugs and nutritional supplements used in the treatment of COVID-19 by people with COVID-19 infection, the reasons for not using them, and the opinions of those who did not have an infection about these drugs; those who had COVID-19 infection mostly used the drugs recommended for treatment (87.5\%); although not recommended, the drugs mostly used were Vitamin $C$, antipyretic drugs and vitamin D; it was observed that $67.4 \%$ of those who did not have COVID-19 infection stated that they would use the drugs to be given in case of having COVID-19 infection and approximately half of them received vitamin supplements. These results show that there is a prejudice in the society regarding drugs for COVID-19 disease, which is a newly described disease in our lives, but the use of drugs in case of disease is not bad in contrast to the prejudices of people in the disease-free group. It was observed that half of the participants were taking medicines and vitamins for prevention and the use of vitamins increased significantly in case of illness.

In our study, it was observed that $65.2 \%$ of the participants' relatives had a COVID-19 infection, and $19.3 \%$ themselves. As of $21 / 04 / 2021$, there are a total of $4,384,624$ cases and 36,613 patients in our country, that is, $0.05 \%$ of the society has had COVID-19 infection. In our study, according to community data, the frequency of people with COVID-19 infection was higher, the reason is related to our sample, but reaching more people with COVID-19 infection than the number of the population was a positive situation for our study to evaluate the drug use of these people. In our study, it was observed that
$79 \%$ of the participants who had COVID-19 infection received outpatient medication. In accordance with our study, a large cohort that included more than 44,000 people with COVID-19 from China, showed that $81 \%$ of the people with COVID-19 have mild symptoms and not hospitalized. ${ }^{[12]}$

Currently, in our country, it is recommended to use Hydroxychloroquine $200 \mathrm{mg}$ tablet and/or Favipiravir 200 mg tablet for 5 days in asymptomatic definite COVID-19 cases where COVID-19 infection will be monitored on an outpatient basis, and in possible/definite COVID-19 treatment with uncomplicated or mild-moderate pneumonia. [8] Prophylactic anticoagulation therapy is recommended to prevent coagulation in some COVID-19 patients. ${ }^{[7]}$ Apart from this, antipyretic drugs, antibiotics and in some cases, vitamins can be recommended. In our study, it was observed that Favipiravir, one of the routinely recommended drugs, was the most administered drug, followed by subcutaneous anticoagulation drugs and Hydroxychloroquine. $87.5 \%$ of the participants who had COVID-19 infection stated that they used the drugs recommended for COVID-19 treatment as described/written on them. It is noteworthy that $87 \%$ of the participants were used regularly/as recommended Favipiravir, which is one of the routinely recommended drugs, and $61.5 \%$ of the Hydroxychloroquine are used regularly/as recommended, and the frequency of use of other recommended drugs is higher than these drugs. Among the reasons for not using the drugs among the participants in our study, the most common reasons were being afraid of its side effects, not seeing it necessary, using herbal products instead of medicines and observing oneself and using it if it deems necessary. It is thought that infodemic may be effective in both the frequency of drug use and the reasons why people do not use it regularly. It is known that there is anxiety against the disease and anxiety in the society for the treatment of COVID-19 infection and its treatment, which is a new disease and new information is added every day. ${ }^{[13,14]}$ In particular, we think that the information obtained from inaccurate sources about the side effects of drugs and the anxiety felt against the disease are effective in the results of our study.

Although not recommended by the physician for those with COVID-19 infection, it has been observed that the most used drugs are Vitamin $C$ and antipyretic drugs, followed by vitamin $\mathrm{D}$ and antibiotics. As a result, for antipyretic and antibiotics, people could not go to the health center due to the need to be isolated at home after being diagnosed with infection, and they may have taken medication according to their own knowledge of their symptoms. For antipyretics, it was recommended to patients with COVID-19 to use antipyretics in case of fever by health professions. ${ }^{[15]} \mathrm{A}$ healthy immune system is very important in preventing viral infections, and vitamins such as A, C, D and E and minerals such as zinc, copper, selenium, and iron are known to play an important role in maintaining a healthy immune response. ${ }^{[16]}$ In addition, since there is no currently approved drug for the treatment of COVID-19, any potential therapeutic that can reduce the severity of the disease 
becomes important for both the prescribing physicians and the public. ${ }^{[17]}$ In our study, it is an expected result that people with COVID-19 infection used vitamins by their own decisions to improve the course of the disease. Vitamin usage rates of participants with COVID-19 infection and the comparison of these rates according to pre-illness (38.4\%), illness period (75\%) and post-illness (45.4\%) and the usage rates of those who did not have COVID-19 infection (51.2\%), the effects of this situation can be seen. According to the distribution, it is noteworthy that the most frequent vitamin supplements were taken during the illness period, and the frequency of use increased after the illness compared to the pre-ill period.

In the study, when the factors affecting the participants' use of drugs as suggested was seen that those have children under 18 years of age, those have chronic diseases and regular drug users used much more regularly and frequently. Chronic diseases are in the first place among the risk factors that increase mortality rates in the COVID-19 epidemic all over the world $^{[18,19]}$ it is thought that this risk may be one of the most important reasons for those with chronic diseases and regular drug users to use the drugs recommended for COVID-19 infection more regularly and frequently than others. It was thought that those with children under the age of 18 may have acted more sensitive on this issue due to the unclear course of this disease in children, ${ }^{[21,22]}$ and the lack of a drug administered to children yet.

In our study, the opinions of those who did not have COVID-19 infection about the drugs to be given by the Ministry of Health/doctors were also evaluated. $32.6 \%$ of these people stated that they would not use the medications given in case of having COVID-19 infection. When these people were asked the reasons, they most frequently stated that they were afraid of the side effects of the drug, drinking 8 tablets at a time was dangerous, observing and thinking about using it myself or fear that the drug would cause permanent damage. It is noteworthy that these people who think that the COVID-19 infection drugs do not prevent the progression of the disease, do not reduce the contagiousness, and reduce the complaints/ symptoms. Again, these results are thought to have negative effects of infodemic. ${ }^{[22]}$

In addition to many reviews or publications about the effects of drugs related to COVID-19 infection in the literature, ${ }^{[15]}$ no study has been found that affects the perceptions and usage of these drugs in the society. In this context, we think that our study will make a significant contribution to the literature. Providing more accurate information on this subject and directing the society to correct information sources should be the first step to be taken in this regard.

Conducting our study online due to the decrease in outpatient applications due to the pandemic and the sociodemographic diversity of the applicants (especially age) is the most important limitation of the study. It cannot be expected that the segment reached in online surveys can be generalized to the whole society.

\section{CONCLUSION}

New information is emerging day by day about the treatment of COVID-19 disease, and this infodemic situation causes the spread of false information about the disease and its treatment both among the public and in scientific circles. The results of our study also support this situation. The healthcare system should be structured in accordance with the pandemic conditions in order to explain the importance of the use of medicines by healthcare workers to the infected people more clearly, to reach the treatment (antipyretic, antibiotic, painkiller, etc.) for their symptoms under the supervision of the doctor, should be avoided. In addition, primary health care workers have a lot of work in order to prevent the prejudices of people who have not had an infection and to improve the perception of drugs in the whole society.

\section{ETHICAL DECLARATIONS}

Ethics Committee Approval: Ethics committee approval of the research was obtained from Hacettepe University NonInterventional Clinical Research Ethics Committee (Date: 19/01/2021, Decision No: GO21/123).

Informed Consent: All patients signed the free and informed consent form.

Referee Evaluation Process: Externally peer-reviewed.

Conflict of Interest Statement: The authors have no conflicts of interest to declare.

Financial Disclosure: The authors declared that this study has received no financial support.

Author Contributions: All of the authors declare that they have all participated in the design, execution, and analysis of the paper, and that they have approved the final version.

\section{REFERENCES}

1. Velavan TP, Meyer CG. The COVID-19 epidemic. Trop Med Int Health 2020;25(3):278-80.

2. WHO (World Health Organization). WHO Coronavirus Disease (COVID-19) Dashboard 2021. https://covid19.who.int/ Accessed: 26.04.2021

3. Republic of Turkey, Ministry of Health. COVID-19 Information Page. https://covid19.saglik.gov.tr/?_Dil=2 Accessed: 26.04.2021

4. Rosenberg ES, Dufort EM, Udo T, et al. Association of treatment with Hydroxychloroquine or azithromycin with in-hospital mortality in patients with COVID-19 in New York State. JAMA 2020;323(24):2493-502.

5. Cao B, Wang $Y$, Wen $D$, et al. A trial of lopinavir-ritonavir in adults hospitalized with severe COVID-19. N Engl J Med 2020;382(19):1787-99.

6. Beigel JH, Tomashek KM, Dodd LE, et al. Remdesivir for the treatment of COVID-19: preliminary report. N Engl J Med 2020;383(10):994.

7. Hacettepe Üniversitesi Tıp Fakültesi COVID-19 Pandemi Raporu (20 Mart20 Kasım). Hacettepe İç Hastalıkları Derneği. https://covid19.tubitak.gov. tr/sites/default/files/inline-files/covid19_pandemi_raporu.pdf Accessed: 26.04.2021

8. T.C. Sağlık Bakanlığı COVID-19 Bilgilendirme Platformu. Erişkin Hasta Tedavisi 2022 Available online: https:/covid19.saglik.gov.tr/TR-66926/ eriskin-hasta-tedavisi.html

9. Hu Z, Yang Z, Li Q, Zhang A. The COVID-19 infodemic: infodemiology study analyzing stigmatizing search terms. J Med Internet Res 2020;22(11):e22639. 
10. The Lancet Infectious Diseases. The COVID-19 infodemic. Lancet Infect Dis 2020;20(8):875.

11. Jovic TH, Ali SR, Ibrahim N, et al. Could vitamins help in the fight against COVID-19? Nutrients 2020; 12(9):2550.

12. Wu Z, McGoogan JM. Characteristics of and important lessons from the Coronavirus Disease 2019 (COVID-19) Outbreak in China: Summary of a report of 72314 cases from the chinese center for disease control and prevention. JAMA 2020;24;323(13):1239-42.

13. Mazza MG, Lorenzo RD, Conte C, et al. Anxiety and depression in COVID-19 survivors: Role of inflammatory and clinical predictors, Brain, Behavior, and Immunity 2020;89: 594-600.

14. Pappa S, Ntella V, Giannakas T, et al. Prevalence of depression, anxiety, and insomnia among healthcare workers during the COVID-19 pandemic: A systematic review and meta-analysis, Brain, Behavior, and Immunity 2020;88: 901-7.

15. Stahlmann R, Lode H. Medication for COVID-19-an overview of approaches currently under study. Dtsch Arztebl Int 2020;117(13):213-9.

16. Karaağaç Y, Bellikci Koyu E. Viral enfeksiyonlarda vitaminler ve mineraller: COVID-19 odağında bir derleme. İzmir Kâtip Çelebi Üniversitesi Sağlık Bilimleri Fakültesi Dergisi 2020; 5(2): 165-73.

17. Bakan S, Deveboynu Şn, Tayhan Kartal F. The effect of antioxidant vitamins on immunity in the COVID-19 pandemic. Eurasian JHS 2020;3(COVID-19 Special Issue): $140-8$

18. Centers for Disease Control and Prevention. People with Certain Medical Conditions 2022 Available online: https://www.cdc.gov/ coronavirus/2019-ncov/need-extra-precautions/people-with-medicalconditions.html

19. Martini N, Piccinni C, Pedrini A, et COVID-19 and chronic diseases: current knowledge, future steps and the MaCroScopio project. Recenti Prog Med 2020;111(4):198-201.

20. Phelps C, Sperry LL. Children and the COVID-19 pandemic. Psychological Trauma: Theory, Research, Practice, and Policy 2020;12(1):73-5.

21. Sinha IP, Harwood R, Semple MG, et al. COVID-19 infection in children. Lancet Respir Med 2020; 8(5): 446-7.

22. Hu Z, Yang Z, Li Q, et al. The COVID-19 infodemic: Infodemiology study analyzing stigmatizing search terms. J Med Internet Res 2020;22(11):e22639. 